\title{
Effects of topical levobunolol or fixed combination of dorzolamide-timolol or association of dorzolamide-levobunolol on intraocular pressure, pupil size, and heart rate in healthy cats
}

\author{
[Efeitos da aplicação tópica do levobunolol, da combinação fixa de dorzolamidatimolol ou da associação de \\ dorzolamida com levobunolol sobre a pressão intra-ocular, o diâmetro pupilar e a \\ freqüencia cardíaca em gatos saudáveis] \\ A.P. Ribeiro ${ }^{1}$, D.P. Junior ${ }^{1}$, T. Champion ${ }^{1}$, M.A. Brunetto ${ }^{1}$, A.A. Camacho $^{2}$, J.L. Laus $^{2 *}$ \\ ${ }^{1}$ Aluno de pós-graduação - FCAV-UNESP - Jaboticabal, SP \\ ${ }^{2}$ Faculdade de Ciências Agrárias e Veterinárias - UNESP \\ Via de Acesso Prof. Paulo Donato Castellane, $\mathrm{s} / \mathrm{n}$ \\ 14884-900 - Jaboticabal, SP
}

\begin{abstract}
The effects of topical levobunolol with the fixed combination of $2 \%$ dorzolamide- $0.5 \%$ timolol and the association of $2 \%$ dorzolamide with $0.5 \%$ levobunolol on intraocular pressure (IOP), pupil size (PS), heart rate (HR), and conjunctival hyperemia in eighteen halthy cats were investigated and compared. IOP, PS, HR, and conjuntival hyperemia were daily recorded at three times (9a.m., 2p.m., and 6p.m.). Three groups were formed $(n=6)$, and one eye of each animal was randomly selected and treated with topical levobunolol (L), or commercial combination of dorzolamide-timolol (DT), or the association of dorzolamide with levobunolol (DL). The first day (0) consisted of recording of baseline values. On the next four consecutive days, drugs were instilled at $8 \mathrm{a} . \mathrm{m}$. and $8 \mathrm{p} . \mathrm{m}$. and measurements were taken at the same times fore cited. Comparing with the baseline values, all evaluated parameters significantly decreased $(\mathrm{P}<0.001)$. Conjuntival hyperemia was not seen. Levobunolol significantly declined IOP, PS, and HR in normal cats, and showed a stronger effect in lowering HR, when compared to dorzolamidetimolol effect. No synergistic effect in IOP declining was noted when levobunolol dorzolamide was added to levobunolol.
\end{abstract}

Keywords: cat, levobunolol, beta-blockers, intraocular pressure, pupil size, heart rate

\section{RESUMO}

Estudaram-se e compararam-se os efeitos do levobunolol, da combinação fixa de dorzolamida 2\%-timolol $0,5 \%$ e da associação de dorzolamida $2 \%$ com levobunolol $0,5 \%$ sobre a pressão intra-ocular (PIO), o diâmetro pupilar (DP), a freqüencia cardiaca (FC) e a hiperemia conjuntival em 18 gatos saudáveis. PIO, $D P, F C$ e hiperemia conjuntival foram aferidos diariamente, em três horários distintos (9h, 14h e 18h). Três grupos foram formados $(n=6)$ e um olho de cada animal recebeu, aleatoriamente, uma gota de levobunolol (L), ou a combinação comercial à base de dorzolamida-timolol (DT), ou a associação de dorzolamida com levobunolol (DL). Parâmetros basais foram aferidos no primeiro dia (dia 0). Nos quatro dias consecutivos, os fármacos foram instilados às $8 \mathrm{~h}$ e $20 \mathrm{~h}$ e os parâmetros aferidos nos mesmos horários. Todos os parâmetros decresceram significativamente em relação aos valores basais $(P<0,001)$ e não se observou hiperemia conjuntival. O levobunolol reduziu significativamente a PIO, o DP e a FC e o foi o fármaco que mais reduziu a FC. Não se observou efeito sinérgico na redução da PIO quando a dorzolamida foi adicionada ao levobulol.

Palavras-chave: gato, levobunolol, beta bloqueadores, pressão intra-ocular, diâmetro pupilar, freqüência cardíaca

Recebido em 13 de agosto de 2007

Aceito em 2 de setembro de 2008

* Autor para correspondência (corresponding author)

E-mail:jllaus@fcav.unesp.br 


\section{INTRODUCTION}

Primary glaucoma in cat is less commonly observed than in dog and the course of the disease is different in this species (Dietrich, 2005). Prostaglandin analogues do not decrease intraocular pressure (IOP) in cats (Studer et al., 2000; Blocker and van der Woerdt, 2001; Hampson et al., 2002; Bartoe et al., 2005). Therefore, it is necessary to evaluate other pharmacological agents, as well as their association in the management of the feline glaucomas. With this purpose, beta blockers, carbonic anhydrase inhibitors, (CAI) and cholinergic agents have been used alone or in association to control IOP in cats (Blocker and van der Woerdt, 2001; Hampson et al., 2002; Dietrich, 2005).

Beta blockers agents include timolol, betaxolol, nipradilol, carteolol, and levobunolol. CAI, such as dorzolamide, also reduces IOP in both healthy (Raibow and Diziezyc, 2003) and glaucomatous cats (Blocker and van der Woerdt, 2001; Hampson et al., 2002; Single et al., 2005). Recently, it was proved that the twice daily dosing of the commercial solution containing dorzolamide-timolol $\left(\right.$ Cosopt $\left.^{\circledR}\right), \quad$ significantly decreased IOP in glaucomatous beagles (Plumer et al., 2006) and in healthy dogs (Borges et al., 2007). In the same study, the authors concluded to be advantageous to use the commercial solution, because fewer instillations are necessary; dorzolamide alone requires three daily doses (Plumer et al., 2006).

The levobunolol hydrochloride is a nonselective adrenergic antagonist of beta- 1 and beta- 2 receptors. The agent decreases IOP up to $3.2 \mathrm{mmHg}$ (Inoue et al., 2005) in human beings with normotensive glaucoma, and up to $7.0 \mathrm{mmHg}$ in those with open angle glaucoma (Akafo et al., 1995).

Considering that both CAI (Raibow and Diziezyc, 2003; Single et al., 2005) and beta blockers (Wilkie and Latimer, 1991; Blocker and van der Woerdt, 2001; Hampson et al., 2002) are able to reduce IOP in cats, it was decided to study and compare the effects of $0.5 \%$ levobunolol and its association to $2 \%$ dorzolamide and with the commercial combination of $2 \%$ dorzolamide- $0.5 \%$ timolol on intraocular pressure, pupil size, heart rate, and conjunctival hyperemia in clinically healthy cats.

\section{MATERIAL AND METHODS}

This study was approved by the Ethics Committee on Animal Experimentation of the Faculdade de Ciências Agrárias e Veterinárias (FCAV) - UNESP, Jaboticabal, São Paulo, Brazil, and followed the ethical norms of the Association for Research in Vision and Ophthalmology - ARVO (National Institutes of Health, Publications no. 85-23, revised 1985).

Eighteen mixed-breed (seven neutered males and 11 spayed females) clinically healthy cats, averaging $4.7 \mathrm{~kg}$, aging from 1.5 to 3 -year-old, were selected from a colony of the Laboratório de Pesquisa em Nutrição e Doenças Nutricionais at the FCAV-UNESP, Jaboticabal, São Paulo, Brazil. As criteria for selection, all subjects were submitted to a complete physical and ophthalmic (Schirmer tear test, biomicroscopy, tonometry, fluorescein staining, and indirect opthalmoscopy) examination in order to exclude cardiac and ophthalmic abnormalities. Once selected, cats were individually housed in metabolic cages measuring $0.5 \mathrm{~m}^{2}$, fed a dry pellet twice daily and water ad libitum. Two days prior to the beginning of the study, the animals underwent physical restraint to acquaint them with procedures (IOP, pupil size, and heart rate), as well as with the investigators.

All ophthalmic procedures were done by the same investigator. Three groups were formed $(n=6)$ with one eye being randomly assigned and treated with $0.5 \%$ levobunolol $^{1}$ (group L), or the commercial combination of $2 \%$ dorzolamide$0.5 \%$ timolol $^{2}$ (group DT), or the association of $2 \%$ dorzolamide ${ }^{3}$ with $0.5 \%$ levobunolol (group DL). The fellow eye of each animal received one drop of saline and served as control. After a single drop of proxymetacaine, ${ }^{4}$ IOP measurements were made by means of applanation tonometry ${ }^{5}$ considering values achieving less than 5\% standard deviation. Horizontal pupil size (PS) was accessed with a Jameson caliper under standard room-light.

\footnotetext{
${ }^{1}$ Betagan $^{\circledR}$, Allergan - Guarulhos, Brasil.

${ }^{2}$ Cosopt ${ }^{\circledR}$, Merck Sharp \& Dohme - São Paulo, Brasil.

${ }^{3}$ Trusopt $^{\circledR}$, Merck Sharp \& Dohme - São Paulo, Brasil

${ }^{4}$ Anestalcon ${ }^{\circledR}$, Alcon - São Paulo, Brasil.

${ }^{5}$ Tono-Pen ${ }^{\circledR}$, Mentor O and O - Norwell, MA, USA.
} 
Electrocardiography was recorded with a computerized electrocardiographic device ${ }^{6}$ and HR was obtained by the R-R interval. All parameters were measured at three differents times (9a.m., 2p.m., and 6p.m.). Day 0 was adopted for collecting the baseline values for IOP, PS, and HR. During the next four consecutive days (day 1 to 4 ), the cats were medicated with the assigned drug at $8 \mathrm{a} . \mathrm{m}$. and 8p.m., and all measurements were recorded at the same times aforementioned. In the group DL, the second drug was instilled after a 10 minute delay. From the day 1 until the end of the experiment, conjunctival hyperemia was recorded using a scale of 0 to 3 (none $=0$; mild $=1$; moderate $=2$; severe $=3$ ).

Overall changes in all parameters accessed among baseline values and post treatment were compared by one way repeated measures analysis of variance with Tukey as a post-hock test $^{7}$. Differences over time were compared by the same tests. A value of $\mathrm{P} \leq 0.05$ was considered significant.

\section{RESULTS}

The mean \pm SEM between oculi sinister (OS) and oculi dexter (OD) on the day 0 was $21.14 \pm 0.43 \mathrm{mmHg}$. IOP of treated eyes significantly decreased when compared to baseline values and control eyes $(\mathrm{P}<0.001)$ in all studied groups. Fig. 1, 2, and 3 summarizes the IOP changes for each of the tested drugs. Throughout the study, only at some times significantly decreased values $(\mathrm{P} \leq 0.05)$, when a comparison between baseline values and control eyes was made. In the same manner, mean \pm SEM of all treated eyes showed variations during the treatment period.

Mean \pm SEM of treated eyes were respectively: $17.4 \pm 0.38 \mathrm{mmHg}$ for the group $\mathrm{L}, 18.25 \pm 0.33$ $\mathrm{mmHg}$ for the group DT, and $17.25 \pm 0.38 \mathrm{mmHg}$ for the group DL. A significant difference was not seen among groups $(\mathrm{P}=0.426)$. In comparison to control eyes, there was a decrease of $2.91,2.13$, and $2.34 \mathrm{mmHg}$, respectively, for the groups L, DT, and DL. The higher and lower means \pm SEM for the treated eyes were $33 \pm 1.80 \mathrm{mmHg}$ and $12.33 \pm 1.28 \mathrm{mmHg}$ for the

${ }^{6}$ ECG-PC, versão $2.07^{\circledR}$, TEB - São Paulo, Brasil.

${ }^{7}$ Systat Software inc ${ }^{\circledR}$ - San Jose, California, USA. group L; $20.00 \pm 1.03 \mathrm{mmHg}$ and $15.00 \pm 0.73 \mathrm{mmHg}$ for the group DT; and $20.33 \pm 0.88$ and $13.00 \pm 0.85 \mathrm{mmHg}$ for the group DL, respectively. No synergistic effect was seen when dorzolamide was added to levobunolol $(\mathrm{P}=0.999)$.

Mean \pm SEM of the pupil aperture between OS and OD on the day 0 was $4.76 \pm 0.14 \mathrm{~mm}$. In all studied groups, pupil size (PS) of the treated eyes was significantly reduced when compared with baseline values $(\mathrm{P}<0.001)$ and control eyes $(\mathrm{P}<0.001)$. Means $\pm \mathrm{SEM}$ for the treated eyes were $3.55 \pm 0.15 \mathrm{~mm}$ for the group $\mathrm{L}$, $3.93 \pm 0.16 \mathrm{~mm}$ for the group DT, and $3.89 \pm 0.14 \mathrm{~mm}$ for the group DL. Significant difference was not seen among groups $(\mathrm{P}=0,327)$. Fig. 4 summarizes the changes in PS for each of the tested drugs. Means \pm SEM of the control eyes in the group DT demonstrated a significant higher value comparatively to baseline values $(\mathrm{P}=0.007)$, group $\mathrm{L}(\mathrm{P}=0.003)$, and group DT $(\mathrm{P}=0.009)$.

In comparison with control eyes, the PS decreased $1.29,1.58$, and $1.02 \mathrm{~mm}$, respectively, for the groups L, DT, and DL. Anisocoria was noted in almost all treated eyes even seven days after the completion of the study.

Heart rate (HR) changes (mean \pm SEM) from baseline values and after the four consecutive days of drug instillations are summarized in Fig. 5. Mean \pm SEM for day 0 was $161.44 \pm 2.86 \mathrm{bpm}$. Higher and lower means \pm SEM during the four consecutive days of treatment were $146.16 \pm 6.54 \mathrm{bpm}$ and $125.66 \pm 6.04 \mathrm{bpm}$ for the group L; $160.66 \pm 6.49 \mathrm{bpm}$ and $126.83 \pm 2.07 \mathrm{bpm}$ for the group DT; and $138.33 \pm 6.46 \mathrm{bpm}$ and $126.33 \pm 3.49 \mathrm{bpm}$ for the group DL, respectively. In all groups, the HR significantly decreased in comparison with baseline values $[-25.53 \mathrm{bpm}$ (L), -17, 69bpm (DT), and -29.11bpm (DL)] $(\mathrm{P}<0,001)$. The overall means \pm SEM from day 1 to 4 were $134.80 \pm 1.92 \mathrm{bpm}$ for the group $\mathrm{L}$, $146.84 \pm 1.79 \mathrm{bpm}$ for the group DT, and $131.34 \pm 1.17 \mathrm{bpm}$ for the group DL, respectively, with significant lower values $(\mathrm{P}<0,001)$ seen in the groups that received levobunolol. Daily variations were more evident in the group DT. Conjunctival hyperemia did not occur at any moment in this study. 


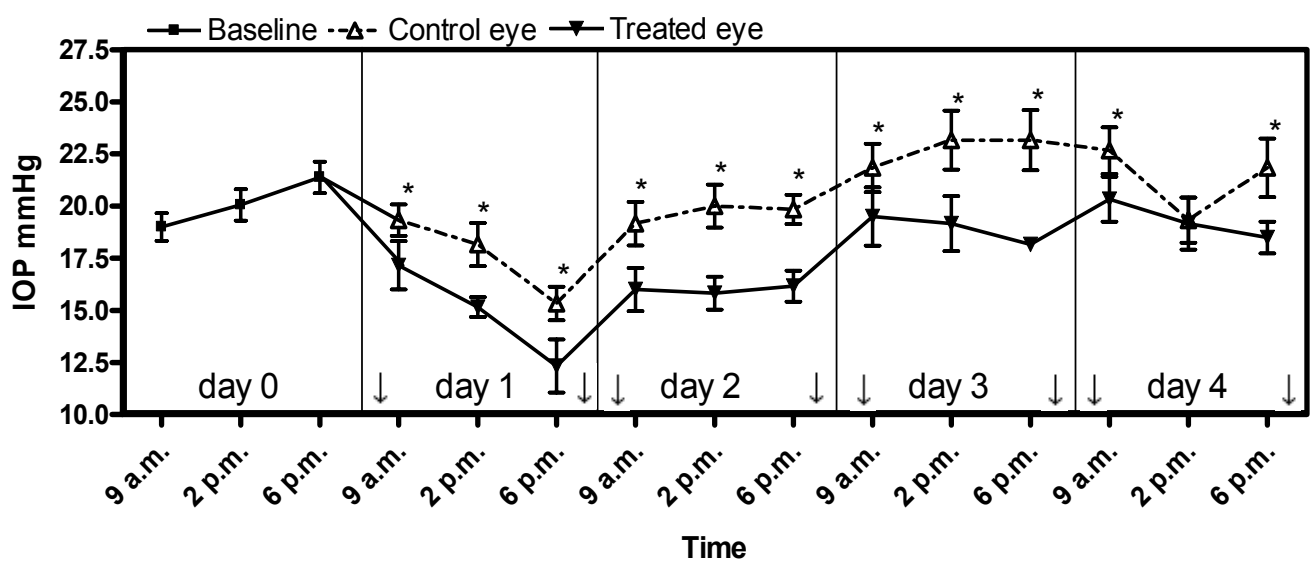

Figure 1. Mean \pm SEM intraocular pressure changes after $0.5 \%$ levobunolol instillations $(\downarrow)$ at 8 a.m and 8p.m. from day 1 to day 4 in normal cats. $* \mathrm{P} \leq 0.05$ significance to the treated eye.

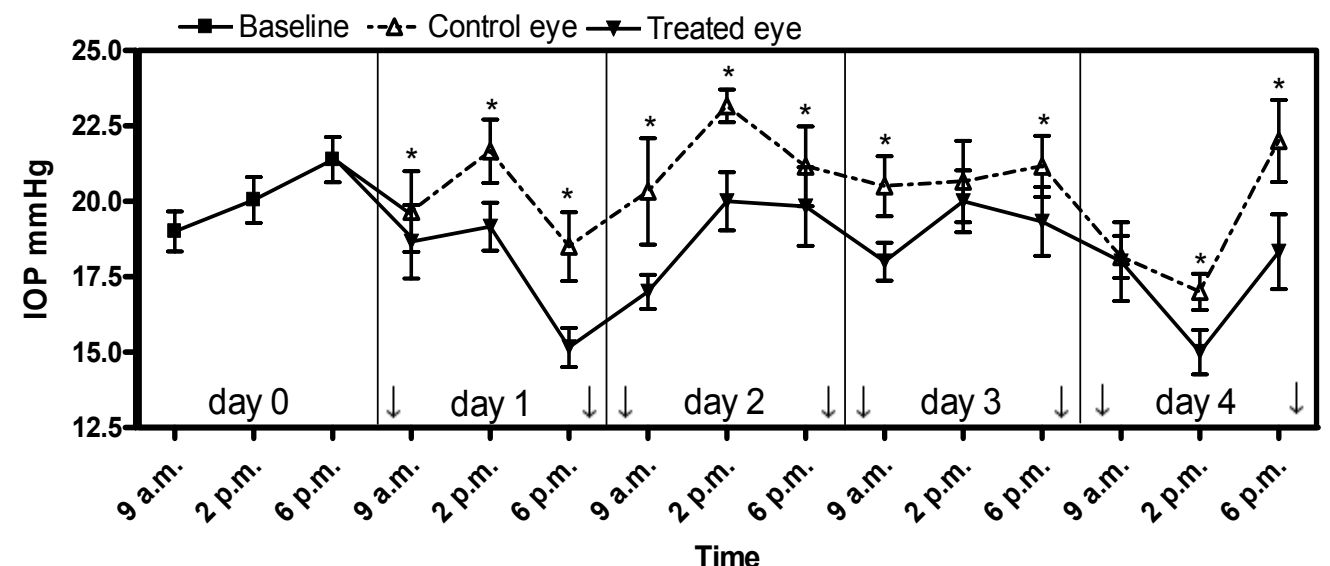

Figure 2. Mean \pm SEM intraocular pressure changes after $2 \%$ dorzolamide- $0.5 \%$ timolol instillations $(\downarrow)$ at 8 a.m and 8p.m. from day 1 to day 4 in clinically normal cats. ${ }^{*} \mathrm{P} \leq 0.05$ significance to the treated eye.

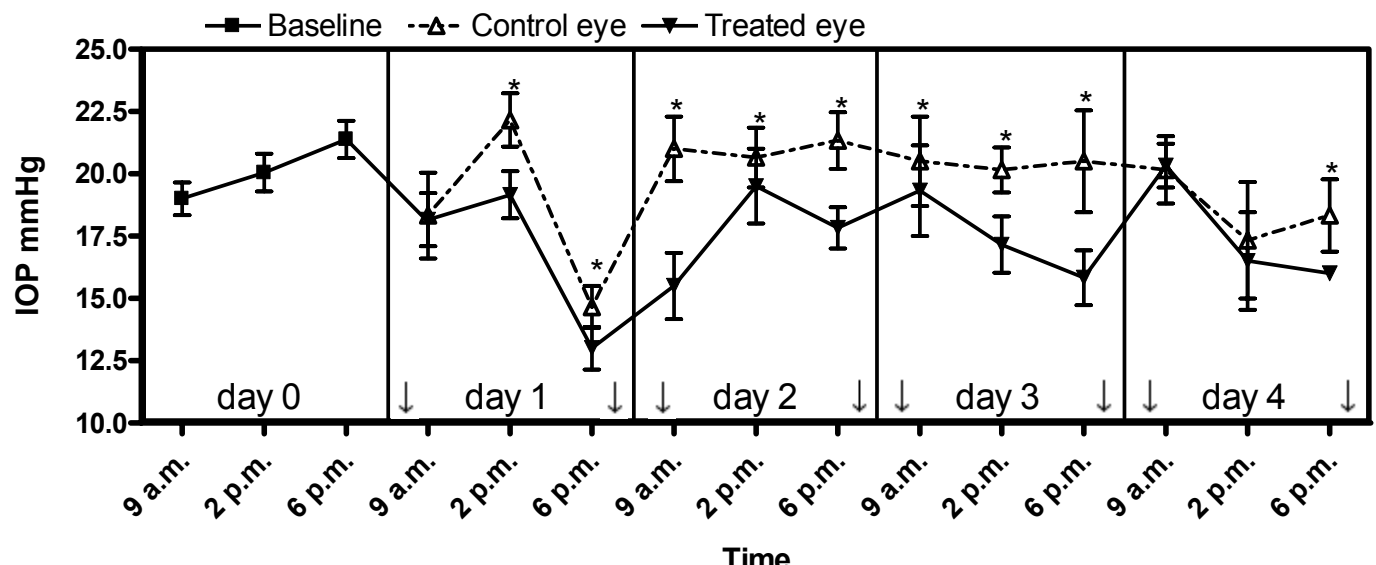

Figure 3. Mean \pm SEM intraocular pressure changes after $2 \%$ dorzolamide- $0.5 \%$ levobunolol instillations $(\downarrow)$ at 8 a.m and 8 p.m. from day 1 to day 4 in clinically normal cats. $* \mathrm{P} \leq 0.05$ significance to the treated eye. 


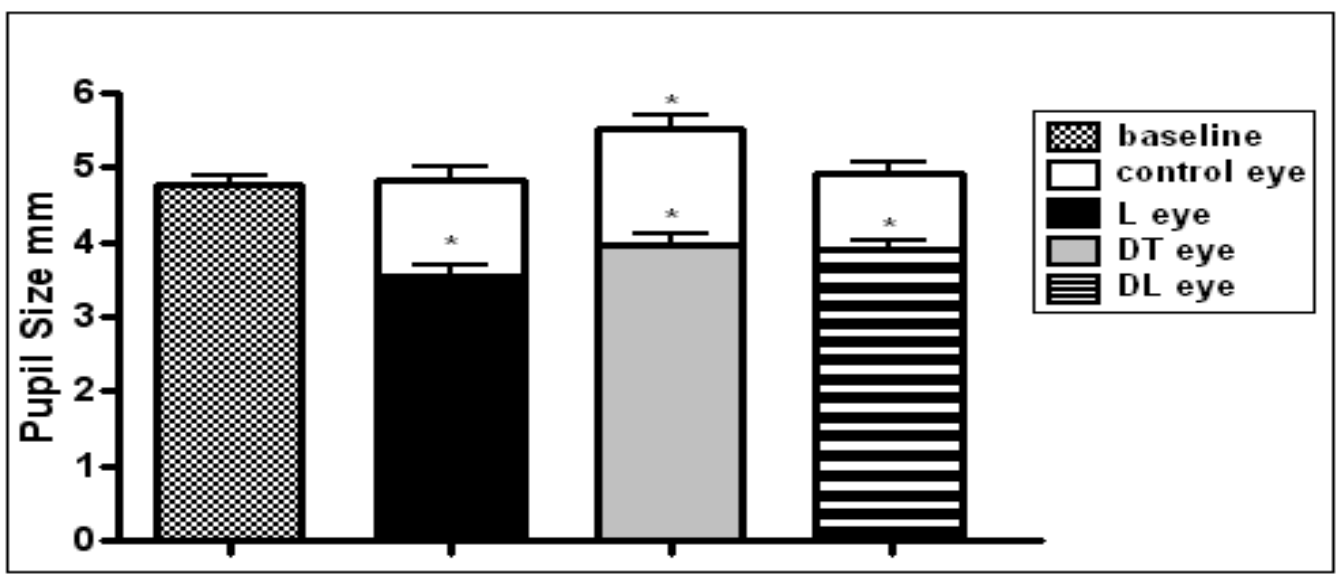

Figure 4. Overall means \pm SEM pupil size changes in all treated eyes (L: levobunolol; DT: dorzolamidetimolol; and DL: dorzolamide-levobunolol) in comparison to the control eyes and baseline values in clinically normal cats. $* \mathrm{P} \leq 0.05$.

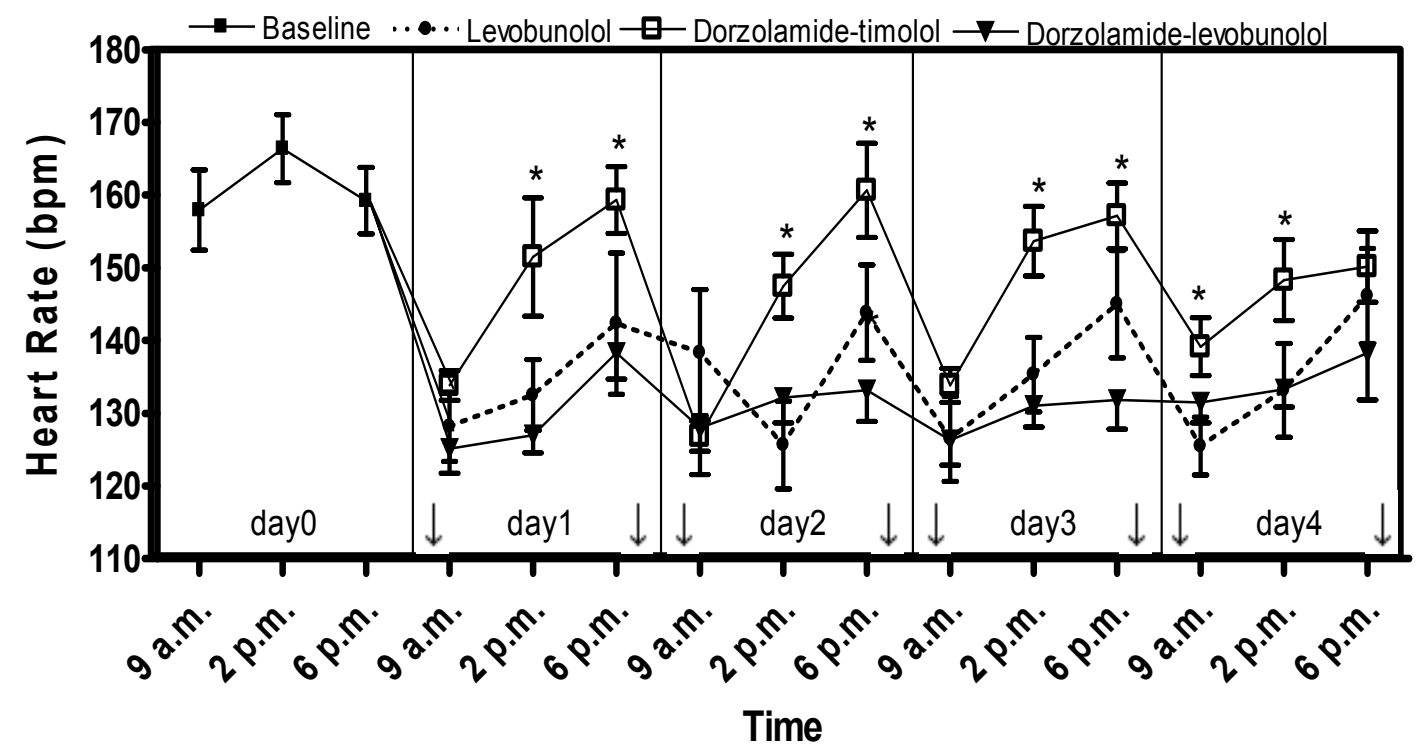

Figure 5. Mean \pm SEM heart rate changes after instillation of all studied drugs $(\downarrow)$ at 8 a.m and 8p.m. from day 1 to day 4 in clinically normal cats. ${ }^{*} \mathrm{P} \leq 0.05$ significance to the group DT.

\section{DISCUSSION}

The reasons for investigating the combination of carbonic anhydrase inhibitors (CAI) with beta blockers include the fact that hypotensive drugs, such as apraclonidine, may have side effects that threaten the health of cats (Wilkie and Latimer, 1991) and also because topical prostaglandins analogues, which strongly decreases IOP in dogs, horses, and human beings are ineffective in cats (Studer et al., 2000; Blocker and van der
Woerdt, 2001; Hampson et al., 2002; Bartoe et al., 2005).

Beta blockers feature non-selective betaadrenoceptor agents such as timolol and levobunolol, beta-1 selective betaxolol, partial beta-1/beta-2 agonist carteolol, and alpha1 nonselective beta blocker nipradilol. They decrease IOP by diminishing the inflow rate of aqueous humor, as a result of beta-adrenoceptor blockade in the ciliary body, decreased aqueous secretion, ultrafiltration, or both (Willis, 2004). It was 
described that nipradilol enhanced uveoscleral outflow in normal dogs (Maehara et al., 2004). For decades, timolol have been used in the management of glaucoma in human and animals (Plumer et al., 2006), and some authors suggested that the most common antiglaucoma medication recommended for cats was timolol maleate (Blocker and van der Woerdt, 2001; Hampson et al., 2002). It was decided to study the effects of topical instillation of $0.5 \%$ hydrochloride levobunolol in the normal feline eye, because references about it were not encountered in the veterinary literature. Although IOP changes have not occurred in an uniform manner in this study, levobunolol significantly decreased IOP by $2.91 \mathrm{mmHg}$, six hours after its first instillation.

The topical association of beta blockers with CAI is more efficacious in controlling elevated IOP, than either of these agents alone, once a synergistic effect occurs between these two pharmacological groups. This is probably due to distinct mechanisms of each drug in blockade aqueous humor genesis at different sites (Willis, 2004; Plumer et al., 2006; Borges et al., 2007).

It was conceived to study the combination of dorzolamide with timolol due to good results that were achieved in regard to IOP in both healthy (Wilkie and Latimer, 1991; Raimbow and Diziezyc, 2003) and glaucomatous cats (Blocker and van der Woerdt, 2001; Hampson et al., 2002; Single et al., 2005) when these drugs were used separatedely. Likewise, it was chosen to associate $2 \%$ dorzolamide with others beta blockers because $1 \%$ brinzolamide, another CAI with notable hypotensive action in dogs, does not act in the same manner in normotensive feline eyes (Gray et al., 2003). The dorzolamidetimolol combination was used because it is commercially available $\left(\mathrm{Cosopt}^{\circledR}\right)$ and reports in glaucomatous beagles (Plumer et al., 2006) and human beings (Straihmainer et al., 1999) have proved a higher effectiveness of this fixed combination to reduce IOP when used twice daily, in comparison to the use of dorzolamide TID and timolol BID alone. Furthermore, this dose schedule could encourage the owner compliance with the treatment, once only BID instillations are necessary instead of administration of a TID drug in addition to a BID drug, besides the elimination of potential washout effects (Plumer et al., 2006).
Surprisingly, no additive effect in the decline of IOP was observed when dorzolamide was associated to levobunolol. Notwithstanding, it was believed that such association may be capable to reduce IOP in glaucomatous cats. Also, is reasonable to infer that increasing the frequency of administration of dorzolamide may result in such effect. Due to its pharmacokinetics, this agent works better when used three times daily (Cawrse et al., 2001; Gelatt and MacKay, 2003). As a matter of fact, when dorzolamide is used as a twice daily regimen, it may take some time for the drug to attain maximal efficacy in both cats (Raimbow and Diziezyc, 2003) and humans (Simpson et al., 1996). Recently, it was verified that TID application of $2 \%$ dorzolamide was able to decrease IOP by $15.4 \mathrm{mmHg}$ in cats with primary congenital glaucoma, and that diurnal elevations in IOP were dampened during the treatment period (Single et al., 2005).

Similarly to levobunolol, the associations of dorzolamide-timolol and dorzolamidalevobunolol, significantly decreased IOP six hours after its first instillation, but a significant difference among agents were not seen. In the present research, IOP reduction of the untreated fellow eye was noted in all groups, but only at some moments, and it was probably due to the beta-blocker effect. Previous publications in which dorzolamide was employed in healthy cats did not elicit such a response (Raimbow and Diziezyc, 2003), whereas in another with timolol, the IOP of the untreated eye was reduced (Wilkie and Latimer, 1991). Diminishing in IOP values of the untreated eye may occur as a result of systemic absorption by part of the agent by the conjuntival vessels (Plumer et al., 2006; Borges et al., 2007).

Studies in human beings comparing the efficacy of levobunolol with timolol have shown that IOP reduction occurs in parallel for both agents. However, a similar effect was observed with a singular daily application of levobunolol in comparison with twice daily applications of timolol (Halper et al., 2002; Ionue et al., 2005). Though the present study did not evaluate the effects of the once daily instillation of levobunolol, one can estimate that the cat would respond favorably to such schedule, due to its slower metabolism. 
Concerning the pupil size (PS), significant miosis could be seen after 90 minutes of the instillation of any tested drug in this study. This finding points to beta adrenergic inhibition or alpha adrenergic activation of the iris sphincter muscle (Willis, 2004). In the group DT, the reduction in the PS may be attributed to timolol, once similar effect was noted in an earlier paper (Wilkie and Latimer, 1991). Although not quantified, miosis could be seen in all treated eyes, even eight days after the completion of this study.

Heart rate reduction of $16.5 \%(\mathrm{~L}), 9 \%$ (DT), and $18.6 \%$ (DL) was noted in all treated animals, with significant lower values seen in groups that received levobunolol. Such intercurrence was also reported in healthy human volunteers (Derrick et al., 1992) and those with primary open angle glaucoma (Halper et al., 2002). Both levobunolol and timolol are nonselective beta blockers, consequently, adverse side effects (i.e. bradycardia, arrhythmias, and atrioventricular block) originating from beta-1 blockade can be found in animals (Willis, 2004) and humans (Chun et al., 1994).

In this study, conjunctival hyperemia was not observed at any time, with any of the tested drugs. Previous researches demonstrated that levobunolol affects pre-corneal tear film stability less than timolol solution (Hashimoto et al., 2006) and that levobunolol produces less ultra-structural changes in the rabbit cornea in comparison to timolol (Jappe et al., 2006). Nevertheless, clinical trials with human beings, proved that treatment with topical timolol elicit fewer adverse events such as burning and stinging of the ocular surface (Halper et al., 2002). Despite of the occurrence of allergic dermatitis (Ishibashi et al., 2003) and iris depigmentation (Polat et al., 1999) had been observed in human beings using topical levobunolol, such events were not seen in this study.

From these results, is feasible to admit that twice daily instillation of levobunolol and the commercial combination of dorzolamide-timolol are safe and able to significantly reduce intraocular pressure, pupil size, and heart rate in clinically healthy cats. However, no synergistic effect in declining IOP was noted when dorzolamide was added to levobunolol. Higher negative chronotropic effect was seen in groups treated with levobunolol, which may preclude its use in patients suffering from atrioventricular block and/or sinus arrest.

\section{ACKNOWLEGMENTS}

The authors wish to thank Dr Aulus Cavalieri Carciofi to allow us to work in the Laboratório de Pesquisa em Nutrição e Doenças Nutricionais of the Faculdade de Ciências Agrárias e Veterinárias - UNESP, Jaboticabal, São Paulo, Brazil.

\section{REFERENCES}

AKAFO, S.K.; THOMPSON, J.R.; ROSENTHAL, A.R. A cross-over trial comparing once daily levobunolol with once daily timolol. Eur. J. Ophthalmol., v.5, p.172176, 1995.

BARTOE, J.T.; DAVIDSON, H.J.; HORTON, M.T. et al. The effect of topical bimatoprost and unoprostone isopropyl on intraocular pressure of normal cats. Vet. Ophthalmol., v.8, p.247-252, 2005.

BLOCKER, T.; van der WOERDT, A. The feline glaucomas: 82 cases (1995-1999). Vet. Ophthalmol., v.4, p.81-85, 2001.

BORGES, A.G.; BRANDÃO, C.V.S.; RANZANI, J.J.T. et al. Efeitos maleato de timolol $0.5 \%$ do cloridrato de dorzolamida $2 \%$ e da associação de ambas na pressão intra ocular. Arq. Bras. Med. Vet. Zootec., v.59, p.660-664, 2007.

CAWRSE, M.A.; WARD, D.A.; HENDRIX, D.V.H. Effects of topical application of a $2 \%$ solution of dorzolamide on intraocular pressure and aqueous humor flow rate in clinically normal dogs Am. J. Vet. Res., v.62, p.859-863, 2001.

CHUN, J.G.; BRODSKY, M.A.; ALLEN, B.J. Syncope, bradycardia, and atrioventricular block associated with topical ophthalmic levobunolol. Am. Heart J., v.127, p.689-690, 1994.

DERRICK, R.J.; ROBIN, A.L.; TIELSCH, J. et al. Once daily levobunolol $(0.5 \%)$ therapy. A cross over study. Ophthalmology, v.99, p.424429, 1992. 
DIETRICH, U. Feline glaucomas. Clin. Tech. Small Anim. Pract., v.20, p.108-116, 2005.

GELATT, K.N.; MacKAY, E.O. Changes in intraocular pressure associated with topical dorzolamide and oral methazolamide in glaucomatous dogs. Vet. Ophthalmol., v.4, p.6167, 2001.

GRAY, H.E.; WILLIS, A.M.; MORGAN, R.V. Effects of topical administration of $1 \%$ brinzolamide on normal cat eyes. Vet. Ophthalmol., v.6, p.285-290, 2003.

HALPER, L.K.; JOHNSON-PRETT, L.; DOBBINS, T. et al. Comparison and tolerability of $0.5 \%$ timolol maleate ophthalmic gel forming solution QD and $0.5 \%$ levobunolol hydrochloride BID in patients with ocular hypertension or open angle glaucoma. $J$. Pharmacol. Ther., v.18, p.105-113, 2002.

HAMPSON, E.C., SMITH, R.; BERNAYS, M.E. Primary glaucoma in Burmese cats. Aust. Vet. J., v.80, p.672-680, 2002.

HASHIMOTO, Y.; ARAGANE, Y.; KAWADA, A. Allergic contact dermatitis due to levobunolol in ophthalmic preparation. $J$. Dermatol., v.33, p.507-509, 2006.

INOUE, K.; EZURE, T.; WAKAKURA, M. et al. The effect of once-daily levobunolol on intraocular pressure in normal-tension glaucoma. Jpn. J. Ophthalmol., v.49, p.56-67, 2005.

ISHIBASHI, T.; YOKOI, N.; KINOSHITA, S. Comparison of the effects of topical levobunolol and timolol on the human ocular surface. Cornea, v.22, p.709-715, 2003.

JAPPE, U.; UTER, W.; MENEZES de PADUA, C.A. et al. Allergic contact due to beta-blockers in eye drops: a retrospective analysis of multicentre surveillance data 1993-2004. Acta Dermatol. Venereol., v.86, p.509-514, 2006.

MAEHARA, S.; ONO, K.; ITO, N. et al. Effects of topical nipradilol and timolol maleate on intraocular pressure, facility of outflow, arterial blood pressure and pulse rate in dogs. Vet. Ophthalmol., v.7, p.147-150, 2004.

PLUMER, C.E.; MacKAY, E.O.; GELATT, K.N. Comparison of the effects of topical administration of a fixed combination of dorzolamide-timolol to monotherapy with timolol or dorzolamide on IOP heart rate in glaucomatous beagles. Vet. Ophthalmol., v.9, p.245-249, 2006.

POLAT, S.; OZDEMIR, N.; SOYLU, M. Ultrastructural effects of topical beta-adrenergic antagonists and alpha-adrenergic agonist on the rabbit cornea. Ophthalmologica, v.213, p.183$188,1999$.

RAIMBOW, M.E.; DIZIEZYC, J. Effects of twice daily application of $2 \%$ dorzolamide on intraocular pressure on normal cats eyes. Vet. Ophthalmol., v.6, p.147-150, 2003.

SIMPSON, A.J.; GRAY, T.B.; BALLANTYNE, C. A controlled clinical trial of dorzolamide: a single-centre subset of a multicentre study. Aust. N.Z. J. Opthalmol., v.24, p.39-42, 1996.

SINGLE, K.J.; MacLELLAN, G.J.; CAMAÑOGARCIA, G. et al. The effect of dorzolamide $2 \%$ on intraocular pressure in cats with primary congenital glaucoma. Vet. Ophthalmol., v.8, p.437-450, 2005.

STRAIHMAINER, K.; SNYDER, E. et al. The efficacy and safety of dorzolamide-timolol combination versus the concomitant administration of its components. Ophthalmology, v.106, p.1-9, 1999.

STUDER, M.E.; MARTIN, C.L.; STILES, J. Effects of $0,005 \%$ latanoptrost solution on intraocular pressure in healthy dogs and cats. Am. J. Vet. Res., v.61, p.1220-1224, 2000.

WILKIE, D.A.; LATIMER, C.A. Effects of topical administration of timolol maleate on intraocular pressure and pupil size in cats. Am. J. Vet. Res., v.52, p.436-440, 1991.

WILLIS, A.M. Ocular hypotensive drugs. Vet. Clin. N. Am.: Small Anim. Pract., v.34, p.755776, 2004. 